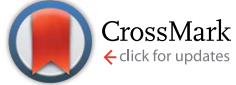

Cite this: RSC Adv., 2015, 5, 83868

\title{
Stabilizing effects of cations on lipases depend on the immobilization protocol $\dagger$
}

\author{
Laura Fernandez-Lopez,ț Rocio Bartolome-Cabrero, $t^{a}$ Maria Daniela Rodriguez, ${ }^{\text {ab }}$

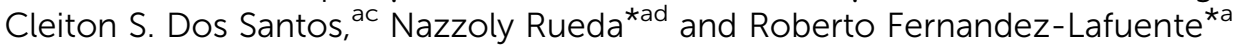

The effect of an additive on enzyme stability used to be considered an intrinsic feature of a lipase. However, in this paper we have found that the effect of additive on enzyme stability depends on the immobilization protocol. After assaying the effects of diverse chloride salts with different cations on different lipases activity, no relevant effect was detected. Free enzymes or the covalently immobilized enzymes are not stabilized by these cations for any of the studied lipases. However, $\mathrm{Mn}^{2+}$ and $\mathrm{Ca}^{2+}$ (at a concentration of $5 \mathrm{mM}$ ) are able to greatly stabilize the lipases from Rhizomucor miehei (RML) and Candida rugosa (CRL) when they are present during the inactivation, but only if the enzymes are immobilized on octyl-agarose (stabilization factor ranging from 20 to 50). The effect was only detected when using more than $2.5 \mathrm{mM}$ of the cations, and reached the maximum value at $5 \mathrm{mM}$, suggesting a saturation mechanism of action. The stabilization seemed to be based on a specific mechanism, and required the recognition sites to be saturated by the cations. $\mathrm{Mg}^{2+}$ has no effect on enzyme stability for both enzymes, but it is able to suppress the stabilization promoted by the other two cations using CRL; while it has no effect on the cation stabilization when using RML. This is the first report of a cation induced enzyme stabilization effect that depends on the lipase immobilization protocol.

Received 8th September 2015 Accepted 25th September 2015

DOI: $10.1039 / c 5 r a 18344 h$

www.rsc.org/advances via genetic tools (site-directed mutagenesis or directed evolution), ${ }^{15-18}$ chemical modification or immobilization, ${ }^{19-25}$ or the use of some stabilizing additives. ${ }^{26-29}$ The use of additives presents some economical and process development drawbacks if used during the final industrial reaction catalyzed by the lipase; they need to be added during each reaction cycle and may complicate the final reaction product purification. These problems are lower during lipase handling, and in fact most industrial soluble enzyme preparations are stabilized by mixtures of different compounds, e.g., saccharides of different nature. ${ }^{30-32}$ Immobilization of enzymes is performed in many instances in the presence of inhibitors or other enzyme stabilizers to avoid the loss of activity associated in some instances to the different steps of an immobilization protocol. ${ }^{33-35}$

Cations may be very simple and cheap additives. The effect of cations on enzyme activity is systematically analyzed in the characterization of new enzymes in many instances. ${ }^{36-39}$ However, the effect of cations on enzyme stability, mainly if the actions lack of effect on enzyme activity, is not usually considered, although in some cases the cation effects are quite relevant. $^{\mathbf{4 0}-43}$ Ions may be very relevant to stabilize the enzyme surface ionic net, forming some ionic crosslinking on specific areas or stabilizing concrete areas by ionic bridges. There are many reports on enzymes that are stabilized by some specific cations, mainly multimeric proteins where the cation plays a critical role in stabilizing the multimeric structure, ${ }^{\mathbf{4 4 , 4 5}}$ and other cases where a stabilization is achieved by the use of a high 
ionic strength, independently of the ions used. Nevertheless, it may be assumed that if a low concentration (e.g., $5 \mathrm{mM}$ ) of an ion has a great positive effect on enzyme stability, this may be used under any circumstance without great problem.

Moreover, the stabilization effect of adequate cations may be coupled to the stabilization achieved via other strategies, like immobilization. In fact, in some instances the role of an ion on enzyme stability could only be disclosed when some inactivation causes were eliminated via immobilization (e.g., preventing multimeric enzyme subunit dissociation). ${ }^{46}$

On the other hand, lipases exist in two different forms. The closed form has the active center isolated from the environment by a polypeptide chain, called lid or flat. The lid has a very hydrophobic internal face that interacts with the hydrophobic areas surrounding the active center. In the open and active form of lipases, the lid moves and exposes the active center to the medium. This open form tends to become adsorbed on hydrophobic surfaces and become stabilized (the so-called interfacial activation). ${ }^{47-50}$ Thus, it is likely that the effect of the cations may differ depending on the use of a lipase interfacially activated versus a hydrophobic surface or lipase formulations where the conformational equilibrium exists. Free enzyme always has the risk of precipitation in the presence of multivalent cations, where lipases also have a tendency to form bimolecular aggregates ${ }^{51,52}$ and conclusions may be difficult to reach with these enzyme formulations.

In this paper, the effect of different cations on the stability of 3 different preparations of two of the most popular lipases, those from Rhizomucor miehei (RML) $)^{53,54}$ and from Candida rugosa (CRL) ${ }^{55,56}$ have been studied.

The effects of the cations on the free enzymes, the enzymes covalently immobilized, where the conformational equilibrium is maintained, and on octyl-agarose, where the open form of the lipases becomes stabilized ${ }^{57}$ have been analyzed. The main objective of the study is too analyze if the effect of an additive is an inherent property of an enzyme, or may be greatly modulated if the immobilization protocol produce different enzyme conformations, as in the current research effort.

\section{Materials and methods}

\subsection{Materials}

Solutions of lipases from Candida antarctica (isoform A) (9.5 mg of protein per $\mathrm{mL}$ ) (CALA), Thermomyces lanuginosus (TLL) (36 mg of protein per $\mathrm{mL}$ ), Lecitase (16 $\mathrm{mg}$ of protein per $\mathrm{mL}$ ) and $\mathrm{RML}$ (13.7 $\mathrm{mg}$ of protein per $\mathrm{mL}$ ) were a kind gift from Novozymes (Spain). Cyanogen bromide crosslinked $4 \%$ agarose (BrCN) beads and octyl-agarose beads were from GE Healthcare. $p$-Nitrophenyl butyrate ( $p$-NPB), diethyl- $p$-nitrophenylphosphate (D- $p$ NPP) and CRL (in powder form, $40 \%$ of protein content) were from Sigma Chemical Co. (St. Louis, MO, USA). All reagents and solvents were of analytical grade. All experiments were performed by triplicate and the results are given as an average with the standard deviation.

\subsection{Determination of enzyme activity}

This assay was performed by measuring the increase in absorbance at $348 \mathrm{~nm}$ produced by the released $p$-nitrophenol in the hydrolysis of $0.4 \mathrm{mM} p$-NPB in $25 \mathrm{mM}$ sodium phosphate at $\mathrm{pH}$ 7.0 and $25{ }^{\circ} \mathrm{C}\left(\varepsilon\right.$ under these conditions is $\left.5150 \mathrm{M}^{-1} \mathrm{~cm}^{-1}\right)$. To start the reaction, $50-100 \mu \mathrm{L}$ of lipase solution or suspension were added to $2.5 \mathrm{~mL}$ of substrate solution. One international unit of activity (U) was defined as the amount of enzyme that hydrolyzes $1 \mu \mathrm{mol}$ of $p$-NPB per minute under the conditions described previously. Only to assess the effect of the cations on enzyme activity, different salts $(5 \mathrm{mM})$ were added to check the effect on the enzyme activity. Protein concentration was determined using Bradford's method ${ }^{58}$ and bovine serum albumin was used as the reference.

\subsection{Immobilization of enzymes}

The enzymes were immobilized under conventional conditions; the cations used in this study were not added in this step.

2.3.1 Immobilization of enzymes on BrCN support. $5 \mathrm{~g}$ of BrCN agarose beads was added to $50 \mathrm{~mL}$ of an enzyme solution (5 $\mathrm{mg}$ of protein per $\mathrm{g}$ of wet support) in $25 \mathrm{mM}$ sodium phosphate at $\mathrm{pH} 7$ containing $0.1 \%(\mathrm{v} / \mathrm{v})$ Triton $\mathrm{X}-100$ to have the monomeric form of the lipases. ${ }^{\mathbf{5 2 5 9}}$ After 90 min at $4{ }^{\circ} \mathrm{C}$ under gentle stirring, the biocatalysts were washed with distilled water and incubated in a solution of $1 \mathrm{M}$ ethanolamine at $\mathrm{pH} 8$ for $2 \mathrm{~h}$ to block the remaining reactive groups in the support. Finally, the immobilized preparations were washed with abundant distilled water and stored at $4{ }^{\circ} \mathrm{C}$. The biocatalysts thus prepared have an immobilization yield of $50 \%$ maintaining almost intact the activity (as has been previously described in other examples using this support). ${ }^{51}$

2.3.2 Immobilization of enzymes on octyl (OC) supports. The immobilization was performed using $1 \mathrm{mg}$ of protein per $\mathrm{g}$ of wet support. The commercial samples of the enzymes were diluted or dissolved in the corresponding volume of $5 \mathrm{mM}$ sodium phosphate at $\mathrm{pH}$ 7. Then, the OC support was added ( $10 \mathrm{~g}$ of support in $100 \mathrm{~mL}$ of enzyme solution). The activity of both supernatant and suspension was followed using $p$-NPB. After immobilization, the suspension was filtered and the supported enzyme was washed several times with distilled water and stored at $4{ }^{\circ} \mathrm{C}$. The enzyme activity increased after immobilization except in the case of CAL, as has been previously described. ${ }^{53,57,60-64}$

\subsection{Thermal inactivation of different enzyme preparations}

This experiment was performed to determine the effect of the cations on the enzyme stability. Free enzyme or $1 \mathrm{~g}$ of immobilized lipases were suspended in $10 \mathrm{~mL}$ of $5 \mathrm{mM}$ of sodium acetate at pH 5 or Tris buffer at pH 7 at different temperatures, containing different concentrations of different salts. Periodically, samples were withdrawn and the activity was measured using $p$-NPB. Half-lives were calculated from the observed inactivation courses.

\subsection{Hydrolysis of $R$ and $S$ methyl mandelate}

This experiment was performed to determine the effect of the cations on the enzyme activity and specificity versus complex substrates of chiral nature. $50 \mathrm{mM}$ solutions of $R$ or $S$ methyl mandelate in $100 \mathrm{mM}$ glycine at pH 7 containing or not $5 \mathrm{mM}$ of 
$\mathrm{CaCl}_{2}$ or $\mathrm{MnCl}_{2}$ were prepared. Reaction was initialized by adding $1 \mathrm{~g}$ of the lipase preparations in $5 \mathrm{~mL}$ of the substrate solution. The suspension was maintained at $25{ }^{\circ} \mathrm{C}$ under continuous stirring. The reaction was followed by RP-HPLC (Spectra Physic SP 100 coupled with an UV detector Spectra Physic SP 8450) using a Kromasil C18 $(15 \mathrm{~cm} \times 0.46 \mathrm{~cm})$ column. Samples $(20 \mu \mathrm{L})$ were injected and eluted at a flow rate of $1.5 \mathrm{~mL} \mathrm{~min}{ }^{-1}$ using acetonitrile/10 $\mathrm{mM}$ ammonium acetate (35:65, v/v) at pH 2.8 as mobile phase and UV detection was performed at $230 \mathrm{~nm}$. The retention times of the acid was $3 \mathrm{~min}$ and of the ester was $7 \mathrm{~min}$. The enzyme activity is given in $\mu \mathrm{mol}$ of mandelic acid per minute under the conditions described above. Activity was determined by triplicate, using a maximum conversion of $20-30 \%$. The data are given as average values.

\subsection{Irreversible inactivation of immobilized lipases by $D$ - pNPP}

Different lipase-immobilized preparations $(1 \mathrm{~g})$ were suspended in $10 \mathrm{~mL}$ of different concentrations of sodium phosphate buffer (from $10 \mathrm{mM}$ to $1 \mathrm{M}$ ) solution at $\mathrm{pH} 7$ and $25{ }^{\circ} \mathrm{C}$. Then, D- $p$ NPP was added up to a concentration of $1 \mathrm{mM}$. Samples of this suspension were withdrawn periodically, and their activities were checked using the $p$-NPB assay.

\section{Results}

\subsection{Effect of some cations on the stability of different lipase preparations}

Free and different immobilized preparations of some enzymes were inactivated at several $\mathrm{T}$ and $\mathrm{pH} 7$ in the presence of diverse chloride salts. OC preparations of TLL, CALB and Lecitase kept their stabilities almost unaltered in the presence of the whole set of assayed cations $\left(\mathrm{Na}^{+}, \mathrm{K}^{+}, \mathrm{Mg}^{2+}, \mathrm{Mn}^{2+}, \mathrm{Ca}^{2+}\right.$ ) (Fig. $\mathrm{S} 1 \dagger$ ).

Using RML and CRL results are quite surprising. While both free enzymes were not stabilized by any of the cations (in fact the inactivation was slightly more rapid in presence of the cations using RML and slight slower using CRL), the stabilization effect is very relevant using the octyl preparations when $5 \mathrm{mM}$ of $\mathrm{Mn}^{2+}$ or $\mathrm{Ca}^{2+}$ were present in the inactivation suspensions (see Fig. 1 and 2). OC-RML stabilization by both cations was really impressive, when the enzyme inactivated in the absence of these cations were almost inactive, the cations permitted the octyl preparations to retain over $90 \%$ of the activity (see Fig. 1). The stabilization observed with both cations were similar (OC-RML half-live improved around 50 folds using $\mathrm{Mn}^{2+}$ and 40 folds using $\mathrm{Ca}^{2+}$ ). OC-CRL stabilization was slightly lower (25 folds using $\mathrm{Ca}^{2+}$ and 30 folds using $\mathrm{Mn}^{2+}$ ) (Fig. 2). In any case, this stabilization permits a qualitative jump: the enzyme in the presence of cations retained over $80 \%$ of the initial activity while the reference had less than $20 \%$.

To check if the lack of effect of the cations on the free enzyme was due to the aggregation of the RML and CRL molecules in the presence of these bivalent cations, both enzymes were covalently immobilized on BrCN. After immobilization, aggregation was impossible, the mild covalent attachment still permitted the open/closed equilibrium, and the effects of the cations should be directly reflected on enzyme stability. Using BrCN-RML (Fig. 1) or BrCN-CRL (Fig. 2), both covalently immobilized enzyme preparations did not become stabilized by any of these cations, results were even closer to the reference than using the free enzyme. The inhibition of the free enzymes by $\mathrm{D}-p \mathrm{NPP}$ was also very similar in presence or absence of these salts, suggesting that the percentage of lipase open-closed molecules remained unaltered.

The lack of effect of the cations on the stability of the free enzyme could be associated to a promotion of enzyme aggregation, which could mask the stabilization effect. However, this may not be the explanation using the covalently immobilized enzyme, where aggregation is no longer possible. Thus, results suggested that the open forms of RML and CRL stabilized versus the hydrophobic surface of octyl supports are the forms that are stabilized by $\mathrm{Mn}^{2+}$ or $\mathrm{Ca}^{2+}$, while the non-absorbed lipases are not stabilized by them, even if the opening/closing equilibria is possible. Stabilization using $\mathrm{Mn}^{2+}$ is slightly higher than using $\mathrm{Ca}^{2+}$ for both enzymes. The lack of effect of $\mathrm{Mg}^{2+}$ suggested that the lipase stabilization produced by $\mathrm{Mn}^{2+}$ and $\mathrm{Ca}^{2+}$ may follow a specific mechanism, perhaps involving adsorption of these cations on some specific places of the enzyme surface.

To analyze if these stabilization effects could be extrapolated to other conditions, the effect of these cations on the whole set of preparations of RML and CRL were assayed at $\mathrm{pH}$ 5. Fig. 3 and 4 show that the results were similar to those found at $\mathrm{pH} 7$. Free RML inactivation rate was accelerated in a clearer way at pH 5 than at pH 7 by the presence of all the cations (Fig. 3), while free CRL stability remained almost unaltered (Fig. 4). BrCN-RML seemed to be marginally stabilized by $\mathrm{Mn}^{2+}$ (a factor of lower than 2) (Fig. 3), while BrCN-CRL stability was not influenced by the studied cations (Fig. 4). Again, a very clear stabilization was observed using $\mathrm{Mn}^{2+}$ and $\mathrm{Ca}^{2+}$ for the $\mathrm{OC}$ preparations. Using OC-RML, stabilization was lower than that detected at pH 7 (20 folds using $\mathrm{Ca}^{2+}$ and 25 folds using $\mathrm{Mn}^{2+}$ ), while using CRL stabilization seem to be very similar (28 times using $\mathrm{Ca}^{2+}$ and 32 folds using $\mathrm{Mn}^{2+}$ ). At alkaline $\mathrm{pH}$ values, both $\mathrm{Ca}^{2+}$ and $\mathrm{Mn}^{2+}$ presented a much reduced solubility; therefore we have focused the study only in neutral and acid $\mathrm{pH}$ values.

The use of $5 \mathrm{mM}$ of these cations during the activity assay did not promote any relevant effect on the lipase activity on any of the different preparations and lipases assayed (Table $\mathrm{S} 1 \dagger$ ). Thus, the main effect of the cations was just the improved stability of the octyl preparation.

We further tried to characterize this stabilization effect.

\subsection{Effect of the concentration of $\mathrm{Mn}^{2+}$ and $\mathrm{Ca}^{2+}$ on the stabilization effect}

The concentrations of both cations were varied from 0 to $25 \mathrm{mM}$ at pH 7. For both enzymes, the behavior was fairly similar with some differences. Fig. 5 shows that at concentrations of both cations of $1 \mathrm{mM}$ or below, the stabilization effect were very small, at $2.5 \mathrm{mM}$ the stabilization was 10-15 folds (except using $\mathrm{Ca}^{2+}$ and OC-RML), the increase of the cation concentration to $5 \mathrm{mM}$ permitted to greatly increase this stabilization effect while a further increase of the cations concentrations to $25 \mathrm{mM}$ 

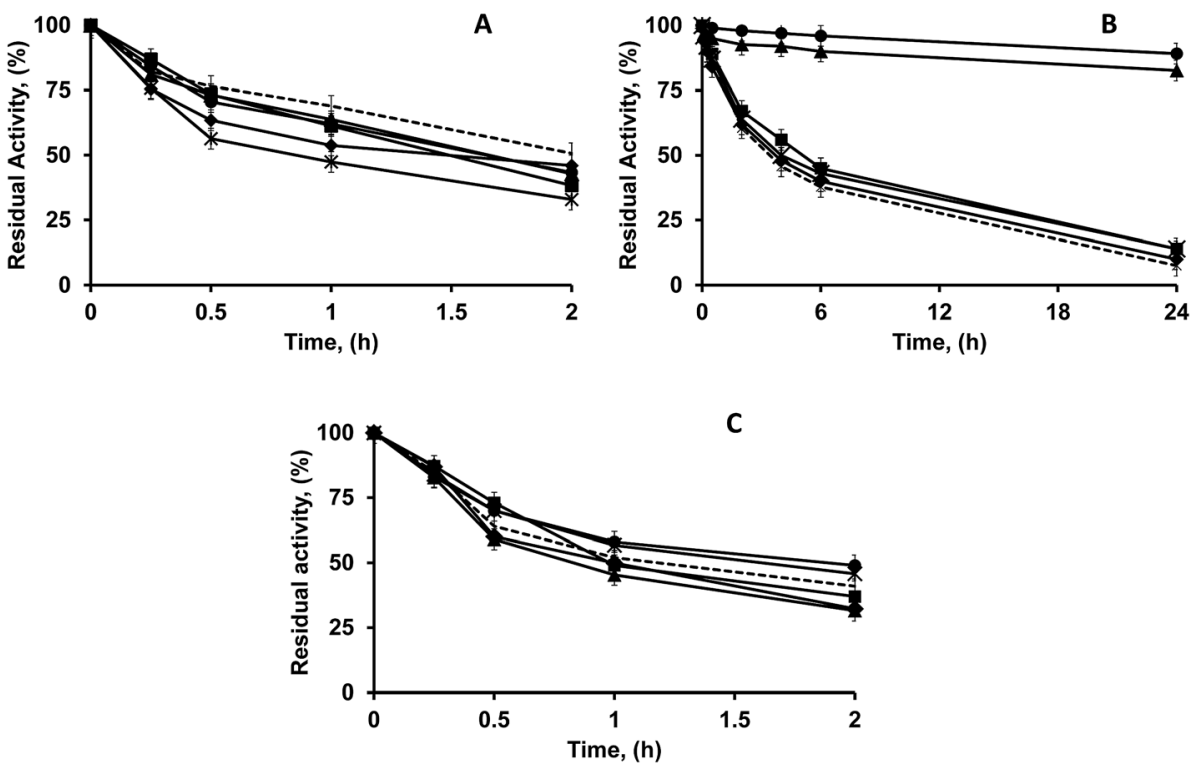

Fig. 1 Stability of different RML preparations in the presence of $5 \mathrm{mM}$ of different chloride salts prepared in $5 \mathrm{mM} \mathrm{Tris} \mathrm{HCl}$ at $\mathrm{pH}$ 7. Panel A: soluble RML, Panel B: OC-RML, Panel C: BrCN-RML. The enzyme preparations were incubated at the indicated temperatures: soluble RML at $45^{\circ} \mathrm{C}, \mathrm{OC}-\mathrm{RML}$ at $45^{\circ} \mathrm{C}$ and $\mathrm{BrCN}-\mathrm{RML}$ at $50^{\circ} \mathrm{C}$. Other specifications are described in Section 2 . Without addition of extra-cations (pointed line), sodium (stars), potassium (rhombus), calcium (triangles), magnesium (squares), manganese (circles).

produced a very slight increase in the stabilizing effect. The highest increase in stability when going from 5 to $25 \mathrm{mM}$ was using $\mathrm{Mn}^{2+}$ and OC-RML. In this case, the increase in stabilization factor was from 50 to 60 . This result suggests that the cation must saturate the stabilization place/places of the enzyme; otherwise the stabilizing effect is not relevant. Moreover, after saturation of these sites, a further increase on the cation concentration has no effect on the enzyme stability.
Next, we study the effect of the combined use of equimolecular mixtures of both stabilizing cations. Using $5 \mathrm{mM}$ of both cations, the results were very similar to the independent use of each of the cations, for both enzymes (results not shown). These results suggest that the effect of both cations were via the same mechanism and not additive. Using $2.5 \mathrm{mM}$ of both cations, where the theoretical site is not fully saturated with any of the cations, observed stabilities were only marginally better
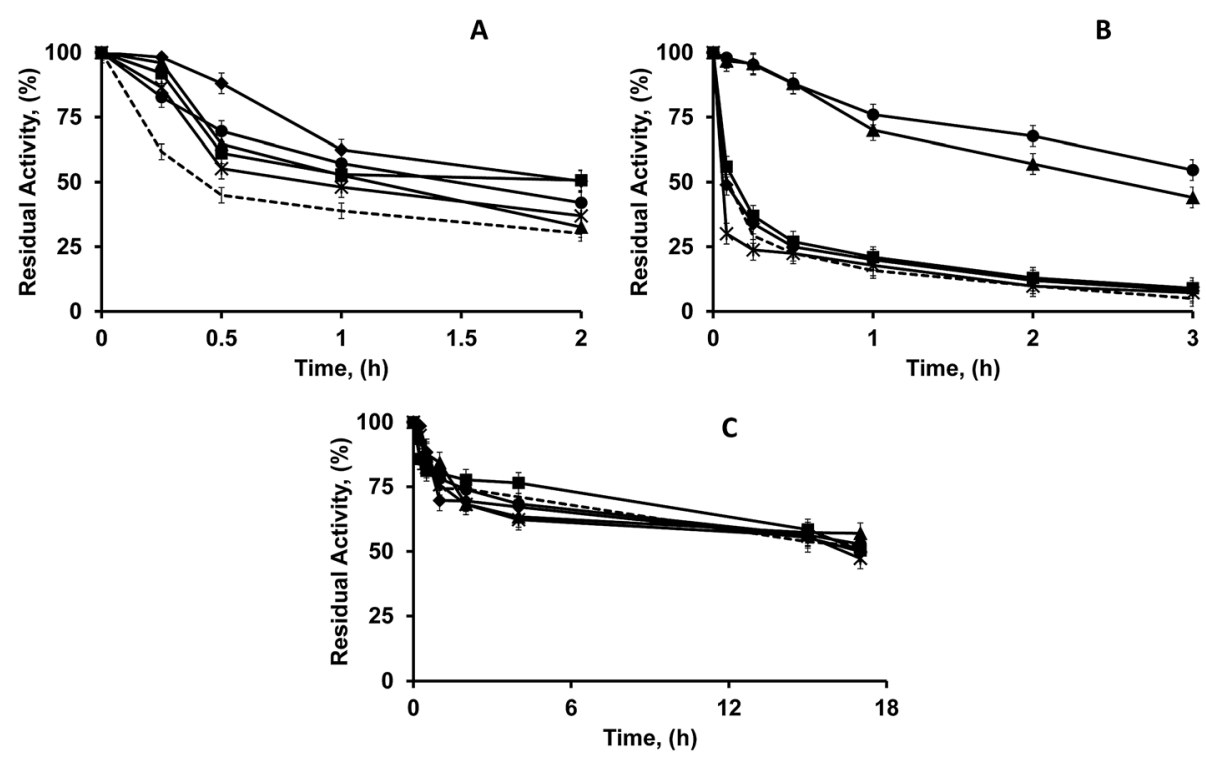

Fig. 2 Stability of different CRL preparations in the presence of $5 \mathrm{mM}$ of different chloride salts prepared in $5 \mathrm{mM} \mathrm{Tris} \mathrm{HCl}$ at $\mathrm{pH}$ 7. Panel A: soluble CRL, Panel B: OC-CRL, Panel C: BrCN-CRL. The enzyme preparations were incubated at the indicated temperatures: soluble CRL at $50{ }^{\circ} \mathrm{C}, \mathrm{OC}-\mathrm{CRL}$ at $60^{\circ} \mathrm{C}$ and $\mathrm{BrCN}-\mathrm{CRL}$ at $55^{\circ} \mathrm{C}$. Other specifications are described in Section 2. Without addition of extra-cation (pointed line), sodium (stars), potassium (rhombus), calcium (triangles), magnesium (squares), manganese (circles). 

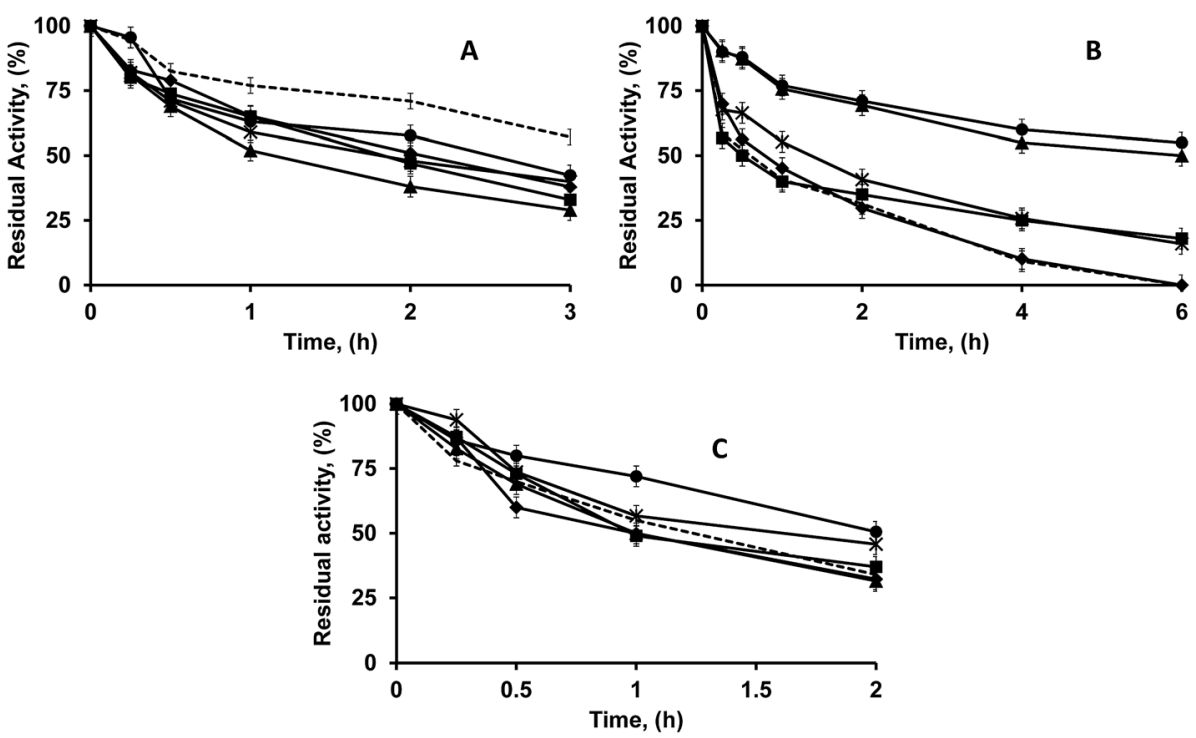

Fig. 3 Stability of different RML preparations in the presence of $5 \mathrm{mM}$ of different chloride salts prepared in $5 \mathrm{mM}$ sodium acetate at pH 5. Panel A: soluble RML, Panel B: OC-RML, Panel C: BrCN-RML. The enzyme preparations were incubated at the indicated: soluble RML at $45^{\circ} \mathrm{C}, \mathrm{OC}-\mathrm{RML}$ at $50{ }^{\circ} \mathrm{C}$ and $\mathrm{BrCN}-\mathrm{RML}$ at $65^{\circ} \mathrm{C}$. Other specifications are described in Section 2. Without addition of extra-cation (pointed line), sodium (stars), potassium (rhombus), calcium (triangles), magnesium (squares), manganese (circles).

that using the individual cations at $2.5 \mathrm{mM}$, and lower than that obtained using $5 \mathrm{mM}$. Thus, $5 \mathrm{mM}$ of $\mathrm{Mn}^{2+}$ or $\mathrm{Ca}^{2+}$ seemed to be necessary to take full advantage of the stabilization produced by these cations.

\subsection{Effect of the concentration of $\mathrm{Mg}^{2+}$ on the stabilizing effects of $\mathrm{Mn}^{2+}$ and $\mathrm{Ca}^{2+}$}

Fig. 6 shows the stabilizing effect of $5 \mathrm{mM}$ of $\mathrm{Mn}^{2+}$ and $\mathrm{Ca}^{2+}$ in the presence of growing concentrations of $\mathrm{Mg}^{2+}$, the divalent cation that did not produce any stabilizing effect. Using OC-CRL, the use of $5 \mathrm{mM}$ de $\mathrm{Mg}^{2+}$ is able to fully suppress the stabilizing effect of both cations at both $\mathrm{pH}$ values. However, the results are very different using OC-RML, where the stability is almost unaffected in the presence of $\mathrm{Mg}^{2+}$ in the presence of $5 \mathrm{mM}$ of the stabilizing cations. This means that $\mathrm{Mg}^{2+}$ may compete for the site(s) where the stabilizing cations are adsorbed using OC-CRL, suggesting that it may become adsorbed on the same place or in another place that make the adsorption of
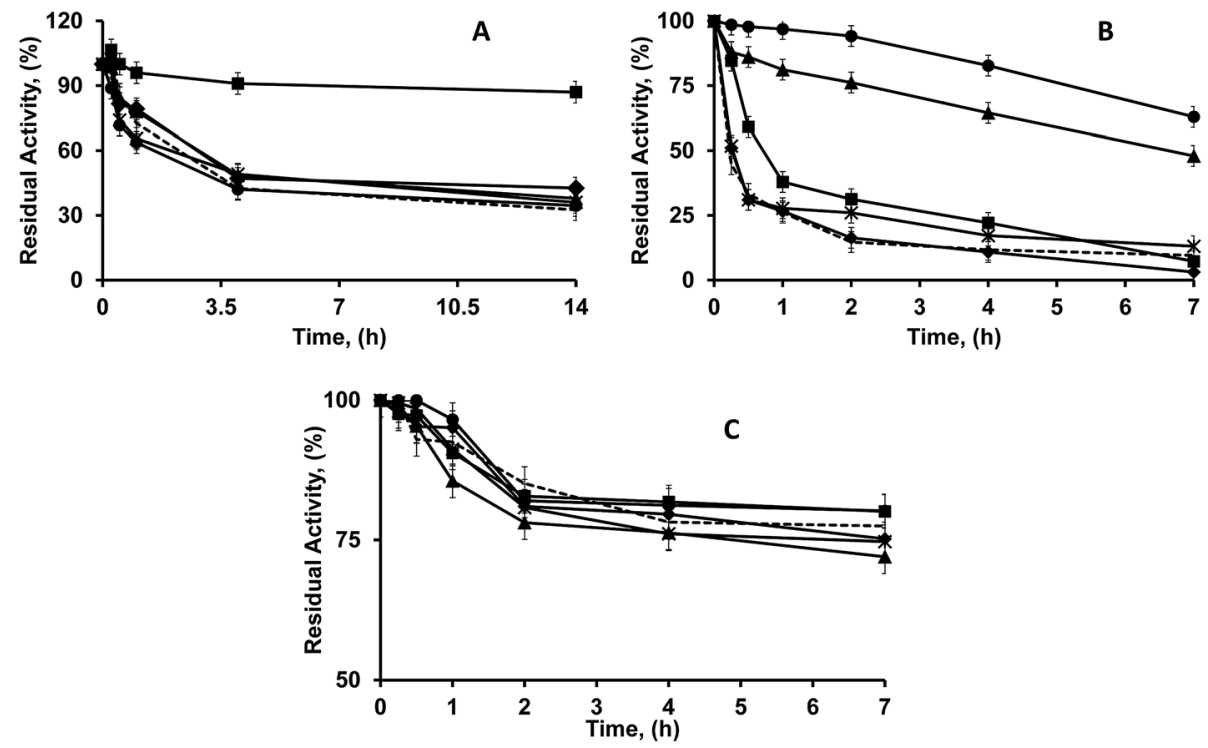

Fig. 4 Stability of different CRL preparations in the presence of $5 \mathrm{mM}$ of different chloride salts prepared in $5 \mathrm{mM}$ sodium acetate at pH 5 . Panel A: soluble CRL, Panel B: OC-CRL, Panel C: BrCN-CRL. The enzyme preparations were incubated at indicated temperatures: soluble $\mathrm{CRL}$ at $50{ }^{\circ} \mathrm{C}$, $\mathrm{OC}-\mathrm{CRL}$ at $58^{\circ} \mathrm{C}$ and $\mathrm{BrCN}-\mathrm{CRL}$ at $60^{\circ} \mathrm{C}$. Other specifications are described in Section 2. Without addition of extra-cation (pointed line), sodium (stars), potassium (rhombus), calcium (triangles), magnesium (squares), manganese (circles). 


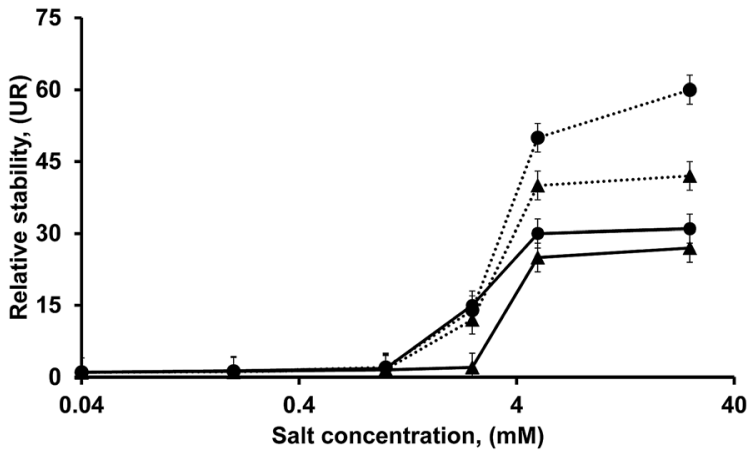

Fig. 5 Effect of $\mathrm{MnCl}_{2}$ and $\mathrm{CaCl}_{2}$, concentrations on the stability of OC-RML (pointed line) and OC-CRL (solid black line). The unit of relative units is considered the half live of the $O C$ preparation in Tris without cations. The inactivation was performed in Tris HCL $5 \mathrm{mM}$ at $\mathrm{pH} 7$ at the mentioned temperatures: RML assays were performed at $45^{\circ} \mathrm{C}$ and $\mathrm{CRL}$ assays at $60^{\circ} \mathrm{C}$. Other specifications are described in Section 2. $\mathrm{CaCl}_{2}$ (triangles), $\mathrm{MnCl}_{2}$ (circles).
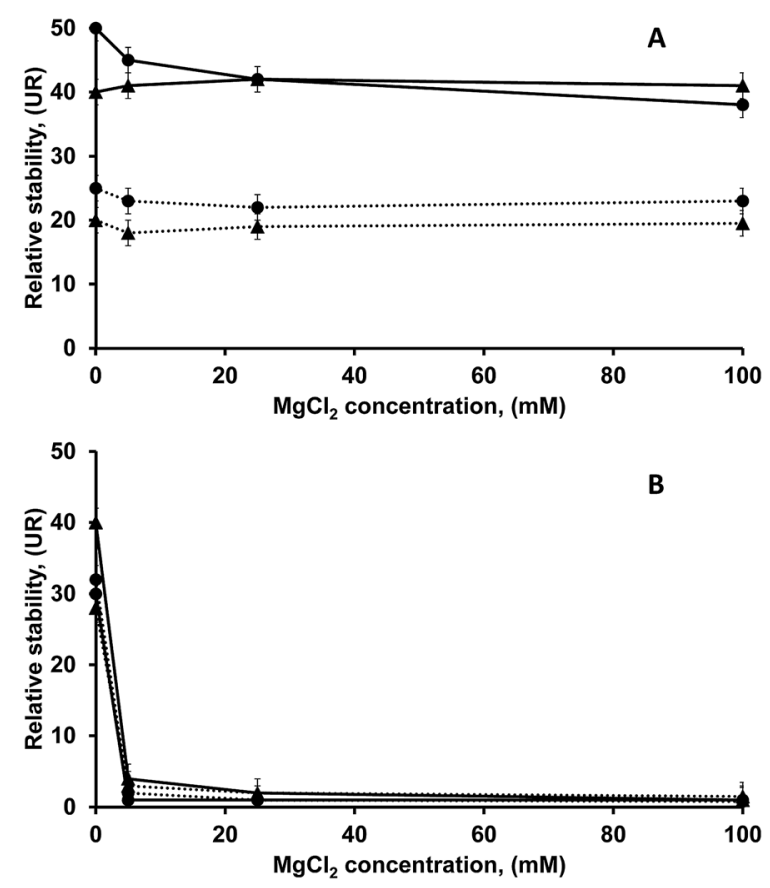

Fig. 6 Effect of the concentration of $\mathrm{MgCl}_{2}$ on the stabilizing effects of $\mathrm{MnCl}_{2}$ and $\mathrm{CaCl}_{2}$ on OC-RML (pointed line) and OC-CRL (solid black line). The unit of Relative Units is considered the stability of the OC preparation in Tris without cations. Enzyme preparations were incubated at specified temperatures: RML assays were performed at $45^{\circ} \mathrm{C}$ and $\mathrm{CRL}$ at $60^{\circ} \mathrm{C}$. Other specifications are described in Section 2. $\mathrm{CaCl}_{2}$ (triangles), $\mathrm{MnCl}_{2}$ (circles).

$\mathrm{Mn}^{2+}$ and $\mathrm{Ca}^{2+}$ to the right place no longer possible (by inducing some conformational change or blocking the entry of the other cations to the right pocket). This hypothetic site of CRL will have an affinity higher than that of the enzyme for the stabilizing cations. This cation did not modify the effect of the stabilizing cations using OC-RML. Thus, or the $\mathrm{Mg}^{2+}$ cannot access to the RML sites where $\mathrm{Mn}^{2+}$ and $\mathrm{Ca}^{2+}$ have an stabilizing role, or the affinity of these places of the enzyme by these cations is far
Table 1 Effect of different cations on the octyl-lipase activity versus $R$ or $S$ methyl mandelate. Enzyme reactions were carried out using as substrate $R$ or $S$ methyl mandelate $(50 \mathrm{mM})$ at $\mathrm{pH} 7$ and $25^{\circ} \mathrm{C}$ as described in Section 2

\begin{tabular}{llll}
\hline Biocatalyst (cation) & $V_{R \text { methyl mandelate }}{ }^{a}$ & $V_{S}$ methyl mandelate ${ }^{a}$ & $V_{R} / V_{S}$ \\
\hline OC RML (none) & $6.5 \pm 0.32$ & $7.0 \pm 0.35$ & 0.93 \\
OC RML $\left(\mathrm{CaCl}_{2}\right)$ & $6.8 \pm 0.34$ & $6.1 \pm 0.31$ & 1.11 \\
OC RML $\left(\mathrm{MnCl}_{2}\right)$ & $7.2 \pm 0.36$ & $7.1 \pm 0.36$ & 1.01 \\
OC CRL (none) & $0.5 \pm 0.03$ & $1.4 \pm 0.07$ & 0.36 \\
OC CRL $\left(\mathrm{CaCl}_{2}\right)$ & $0.6 \pm 0.03$ & $1.3 \pm 0.08$ & 0.46 \\
OC CRL $\left(\mathrm{MnCl}_{2}\right)$ & $0.6 \pm 0.03$ & $1.4 \pm 0.06$ & 0.43 \\
${ }^{a}$ Activity $\left(\times 10^{3}\right)$ & & & \\
\hline
\end{tabular}

higher than that by $\mathrm{Mg}^{2+}$ (perhaps by this reason we have not found a stabilizing effect of this).

\subsection{Effect of the presence of cations in the specificity of RML and CRL}

It has been reported in many instances that the lipase specificity may be easily altered by any strategy that may alter the final conformation of the enzyme, for example the immobilization via different protocols. ${ }^{60-62}$ In the first section of this paper, we have showed that the cations have not effect on the catalytic activity of the lipases in a very simple reaction, the hydrolysis of $p$-NPB. Now, the enzyme activity versus a more complex substrate is analyzed: $R$ or $S$ methyl mandelate has been hydrolyzed using octyl-RML or CRL in presence or absence of $\mathrm{CaCl}_{2}$ or $\mathrm{MnCl}_{2}$. This compound has an aromatic ring and a hydroxyl group in the alpha position. Table 1 shows that neither RML nor CRL are greatly affected by these stabilizing cations in their catalytic activities versus this substrates. This suggested that the stabilizing role of these cations did not involve a conformational change of the octyl preparations, but just they reinforce the overall enzyme structure.

\section{Conclusion}

The immobilization protocol has been shown to have a critical role in the lipase features. The same chemical modification or physical coating of differently immobilized biocatalysts of lipases has been described to promote very different effects on the enzyme properties, like selectivity or specificity. ${ }^{51-54,60-62}$ However, this is the first report where a simple additive, like a cation, is found to produce a high stabilization of only some immobilized preparations of an enzyme and this effect is not found or is much less intense on other enzyme preparations, including the free enzyme. This may be caused by the very different forms of the two immobilized enzyme preparations: the OC-lipase has the open form adsorbed and stabilized on the hydrophobic surface of OC supports, ${ }^{57}$ while BrCN immobilized lipase maintains the equilibrium between closed and open conformation (non-stabilized by adsorption to a hydrophobic surface). Thus, while studying the free enzyme, the researcher will deduce a lack of stabilizing effect of $\mathrm{Mn}^{2+}$ or $\mathrm{Ca}^{2+}$, correlated to a lack of effect on the enzyme activity and specificity, 
using OC-immobilized enzymes the stabilization may be measured in dozens folds, constituting a real qualitative stabilization. This becomes a new advantage of the immobilization of these two enzymes on octyl supports. ${ }^{57}$

Thus, the use of $5 \mathrm{mM}$ of salts containing $\mathrm{Mn}^{2+}$ or $\mathrm{Ca}^{2+}$ may be used as a way to greatly increase the enzyme stability in aqueous media during biocatalyst operation at $\mathrm{pH}$ values ranging from 5 to 7 ; alkaline $\mathrm{pH}$ could not be analyzed due to problems in the salts solubility. This low cation concentration may have a low economic impact used even during operation, and in some cases may not be a great problem for the downstream of the final product. Moreover, this low concentration of these cations may be used during storage and handling of the OC immobilized RML or CRL, enlarging the range of conditions where the enzymes may be utilized. ${ }^{\mathbf{6 3 , 6 4}}$ This way, these results may open new possibilities for the use and handling of these interesting immobilized enzymes. The mechanism of stabilization by cations of these OC-lipase preparations require further studies to determine the real nature, perhaps using differential scanning fluorimetry or by isothermal titration calorimetry.

From the results presented in this paper, it is more relevant that the researcher cannot expect that a stabilizing (or perhaps a destabilizing) effect attributed to a particular compound is an inherent feature of an enzyme in all their formulations. This makes necessary to perform the study of stabilization/ destabilization of an enzyme biocatalyst each time that the immobilization protocol is changed. The results of this paper show that the extrapolation of one result from one enzyme preparation to other preparation may be very risky.

\section{Acknowledgements}

We gratefully recognize the support from the MINECO from Spanish Government, (project number CTQ2013-41507-R). The predoctoral fellowships for Ms Rueda (Colciencias, Colombian Government and Becas Iberoamérica "Jóvenes Investigadores", Banco Santander) and for Ms Rodríguez (CONICET and SPU, Argentine Government) and Dr dos Santos (CNPq, Brazil) are also recognized. The authors wish to thank Mr Ramiro Martínez (Novozymes, Spain) for kindly supplying some of the enzymes used in this research. The help and comments from Dr Ángel Berenguer (Instituto de Materiales, Universidad de Alicante) are kindly acknowledged.

\section{References}

1 K. E. Jaeger and T. Eggert, Curr. Opin. Biotechnol., 2002, 13, 390-397.

2 R. Sharma, Y. Chisti and U. C. Banerjee, Biotechnol. Adv., 2001, 19, 627-662.

3 K. E. Jaeger and M. T. Reetz, Trends Biotechnol., 1998, 16, 396-403.

4 R. D. Schmid and R. Verger, Angew. Chem., Int. Ed., 1998, 37, 1608-1633.
5 A. Pandey, S. Benjamin, C. R. Soccol, P. Nigam, N. Krieger and V. T. Soccol, Biotechnol. Appl. Biochem., 1999, 29(Pt 2), 119-131.

6 J. Zhang, H. Shi, D. Wu, Z. Xing, A. Zhang, Y. Yang and Q. Li, Process Biochem., 2014, 49, 797-806.

7 P. Adlercreutz, Chem. Soc. Rev., 2013, 42, 6406-6436.

8 K. Hult and P. Berglund, Trends Biotechnol., 2007, 25, 231238.

9 M. Svedendahl, K. Hult and P. Berglund, J. Am. Chem. Soc., 2005, 127, 17988-17989.

10 M. Kapoor and M. N. Gupta, Process Biochem., 2012, 47, 555569.

11 C. Li, X.-W. Feng, N. Wang, Y.-J. Zhou and X.-Q. Yu, Green Chem., 2008, 10, 616.

12 E. Busto, V. Gotor-Fernández and V. Gotor, Chem. Soc. Rev., 2010, 39, 4504-4523.

13 K. M. Polizzi, A. S. Bommarius, J. M. Broering and J. F. Chaparro-Riggers, Curr. Opin. Chem. Biol., 2007, 11, 220-225.

14 D. C. Demirjian, F. Morís-Varas and C. S. Cassidy, Curr. Opin. Chem. Biol., 2001, 5, 144-151.

15 F. H. Arnold and A. A. Volkov, Curr. Opin. Chem. Biol., 1999, 3, 54-59.

16 U. T. Bornscheuer and M. Pohl, Curr. Opin. Chem. Biol., 2001, 5, 137-143.

17 V. G. H. Eijsink, S. GÅseidnes, T. V. Borchert and B. van Den Burg, Biomol. Eng., 2005, 22, 21-30.

18 O. Kuchner and F. H. Arnold, Trends Biotechnol., 1997, 15, 523-530.

19 P. V. Iyer and L. Ananthanarayan, Process Biochem., 2008, 43, 1019-1032.

20 D. Brady and J. Jordaan, Biotechnol. Lett., 2009, 31, 16391650.

21 C. Ó'Fágáin, Enzyme Microb. Technol., 2003, 33, 137-149.

22 L. Gianfreda and M. R. Scarfi, Mol. Cell. Biochem., 1991, 100, 97-128.

23 S. S. Wong and L. J. C. Wong, Enzyme Microb. Technol., 1992, 14, 866-874.

24 S. Janeček, Process Biochem., 1993, 28, 435-445.

25 V. Stepankova, S. Bidmanova, T. Koudelakova, Z. Prokop, R. Chaloupkova and J. Damborsky, ACS Catal., 2013, 3, 2823-2836.

26 H. Zhao, J. Mol. Catal. B: Enzym., 2005, 37, 16-25.

27 A. Pollard and R. G. Wyn Jones, Planta, 1979, 144, 291-298.

28 J. M. Obón, A. Manjón and J. L. Iborra, Enzyme Microb. Technol., 1996, 19, 352-360.

29 W. A. Jensen, J. M. Armstrong, J. de Giorgio and M. T. W. Hearn, Biochim. Biophys. Acta, Protein Struct. Mol. Enzymol., 1996, 1296, 23-34.

30 S. de Cordt, M. Hendrickx, G. Maesmans and P. Tobback, Biotechnol. Bioeng., 1994, 43, 107-114.

31 S. de Cordt, I. Avila, M. Hendrickx and P. Tobback, Biotechnol. Bioeng., 1994, 44, 859-865.

32 K. Gekko and S. Koga, J. Biochem., 1983, 94, 199-205.

33 R. M. Blanco and J. M. Guisan, Enzyme Microb. Technol., 1988, 10, 227-232. 
34 C. M. Rosell, R. Fernandez-Lafuente and J. M. Guisan, Biocatal. Biotransform., 1995, 12, 67-76.

35 G. Alvaro, R. Fernandez-Lafuente, R. Blanco and J. Guisan, Enzyme Microb. Technol., 1991, 13, 210-214.

36 L. G. Foe and J. L. Trujillo, Arch. Biochem. Biophys., 1980, 199, 1-6.

37 J. C. Warren and S. G. Cheatum, Biochemistry, 1966, 5, 17021707.

38 G. Žoldák, M. Sprinzl and E. Sedlák, Eur. J. Biochem., 2004, 271, 48-57.

39 P. H. von Hippel and T. Schleich, Acc. Chem. Res., 1969, 2, 257-265.

40 D. B. Wright, D. D. Banks, J. R. Lohman, J. L. Hilsenbeck and L. M. Gloss, J. Mol. Biol., 2002, 323, 327-344.

41 P. H. von Hippel and K. Y. Wong, J. Biol. Chem., 1965, 240, 3909-3923.

42 K. D. Collins, Proc. Natl. Acad. Sci. U. S. A., 1995, 92, 55535557.

43 J. A. Harmony, P. J. Shaffer and R. H. Himes, J. Biol. Chem., 1974, 249, 394-401.

44 R. Fernandez-Lafuente, Enzyme Microb. Technol., 2009, 45, 405-418.

45 C. Garcia-Galan, O. Barbosa and R. Fernandez-Lafuente, Enzyme Microb. Technol., 2013, 52, 211-217.

46 S. Kaddour, F. López-Gallego, T. Sadoun, R. FernandezLafuente and J. M. Guisan, J. Mol. Catal. B: Enzym., 2008, 55, 142-145.

47 R. Verger, Trends Biotechnol., 1997, 15, 32-38.

48 C. Cambillau, S. Longhi, A. Nicolas and C. Martinez, Curr. Opin. Struct. Biol., 1996, 6, 449-455.

49 A. M. Brzozowski, U. Derewenda, Z. S. Derewenda, G. G. Dodson, D. M. Lawson, J. P. Turkenburg, F. Bjorkling, B. Huge-Jensen, S. A. Patkar and L. Thim, Nature, 1991, 351, 491-494.

50 K. K. Kim, H. K. Song, D. H. Shin, K. Y. Hwang and S. W. Suh, Structure, 1997, 5, 173-185.
51 G. Fernández-Lorente, J. M. Palomo, M. Fuentes, C. Mateo, J. M. Guisán and R. Fernández-Lafuente, Biotechnol. Bioeng., 2003, 82, 232-237.

52 J. M. Palomo, C. Ortiz, G. Fernández-Lorente, M. Fuentes, J. M. Guisán and R. Fernández-Lafuente, Enzyme Microb. Technol., 2005, 36, 447-454.

53 R. C. Rodrigues and R. Fernandez-Lafuente, J. Mol. Catal. B: Enzym., 2010, 64, 1-22.

54 R. C. Rodrigues and R. Fernandez-Lafuente, J. Mol. Catal. B: Enzym., 2010, 66, 15-32.

55 M. Cygler and J. D. Schrag, Biochim. Biophys. Acta, 1999, 1441, 205-214.

56 P. Domínguez de María, J. M. Sánchez-Montero, J. V. Sinisterra and A. R. Alcántara, Biotechnol. Adv., 2006, 24, 180-196.

57 E. A. Manoel, J. C. S. dos Santos, D. M. G. Freire, N. Rueda and R. Fernandez-Lafuente, Enzyme Microb. Technol., 2015, 71, 53-57.

58 M. M. Bradford, Anal. Biochem., 1976, 72, 248-254.

59 J. M. Palomo, M. Fuentes, G. Fernández-Lorente, C. Mateo, J. M. Guisan and R. Fernández-Lafuente, Biomacromolecules, 2003, 4, 1-6.

60 J. C. S. dos Santos, C. Garcia-Galan, R. C. Rodrigues, H. B. de Sant'Ana, L. R. B. Gonçalves and R. Fernandez-Lafuente, Enzyme Microb. Technol., 2014, 60, 1-8.

61 C. Garcia-Galan, J. C. S. dos Santos, O. Barbosa, R. Torres, E. B. Pereira, V. C. Corberan, L. R. B. Gonçalves and R. Fernandez-Lafuente, Process Biochem., 2014, 49, 604-616.

62 O. Barbosa, M. Ruiz, C. Ortiz, M. Fernández, R. Torres and R. Fernandez-Lafuente, Process Biochem., 2012, 47, 867-876.

63 A. Suescun, N. Rueda, J. C. S. dos Santos, J. J. Castillo, C. Ortiz, R. Torres, O. Barbosa and R. Fernandez-Lafuente, Process Biochem., 2015, 50, 1211-1217.

64 N. Rueda, J. C. S. dos Santos, R. Torres, O. Barbosa, C. Ortiz and R. Fernandez-Lafuente, RSC Adv., 2015, 5, 55588-55594. 